\title{
Difficulties encountered in a community-based study of acute respiratory infections in Uruguay *
}

\author{
Maria Hortal**, Miguel Meny** \\ HORTAL, M. \& MENY, M. Difficulties encountered in a community-based study of acute \\ respiratory infections in Unuguay. Rev. Saude Pública, 27: 123-6, 1993. A cohort study on acute \\ respiratory infections, involving 270 children observed ty pediatricians in their homes every 10 days \\ over a period of 32 months, gave the opportunity to experience logistic and methodological problems \\ seldom described in the literature. The purpose of $t^{*}$ is article is to alert researchers as to the \\ difficulties faced when performing community-based studies in developing countries. Although a \\ carefully planned project was undertaken, problem areas included the establishment of the target \\ population, population dynamics, field related problems, laboratory aspects and data management. It \\ is hoped that other investigators may benefit from the extensive experience gained from our program \\ in foreseeing and coping with the difficulties involved.
}

Keywords: Respiratory tract infection, epidemiology. Cohort studies. Epidemiologic factors.

\section{Introduction}

A longitudianl study of acute respiratory infections (ARI) was carried out among children aged less than 5 years of age from a deprived urban population ${ }^{4}$, between May 1985 and December 1987. A cohort of 270 children was observed by pediatricians in their homes every 10 days over a 32 month period. The specific objectives were to collect basic data on ARI incidence, prevalence, frequency of respiratory syndromes, etiologies and risk factors.

Similar ARI studies were performed simultaneosly in 12 developing countries. Although the studies were not identical because of local interests and needs, all included a basic set of data considered to be of key importance for assessing the magnitude of the ARI problem and for planning interventions. The agency that funded these studies organized coordination meetings of the participants for the purpose of agreeing on standards, the careful design of protocols, the definition of clinical and scientific terms, and the establishment of standard laboratory techniques. Uniform, quality controlled reagents for etiologic diagnosis were made available to the investigators.

* Financial support by the U.S. Academy of Sciences/ National Research Council by means of a grant from the U.S. Agency for International Development.

* Microbiology Unit, Central Public Health Laboratory, Epidemiology Division, Ministry of Public Health Montevideo - Uruguay.

Reprints: M. Hortal - Av. 8 de Octubre 2720 - Montevideo 11.660 - Uruguay.
In the present paper, some of the potential pitfalls in the methodological analysis will be defined as well as some of the logistic challenges faced in Uruguay as the work progressed.

The description of the problems encountered may prove to be useful for future studies, because analyses of difficulties associated with this kind of investigation in developing countries are scarce in the literature ${ }^{3,8}$. Problem areas to be addressed include those associated with the establishment of the target population, population dynamics, field related problems, laboratory aspects and data management. Some of these issues may be detailed as follows.

\section{Target Population}

According to infant mortality rates in Uruguay, children receiving the free health care of the Ministry of Public Health, had higher mortality than those cared for by paid health agencies ${ }^{1}$. This study was carried out in Cerrito, an area where the infant mortality rate was 52.0 per 1,000 live births while the national infant mortality rate for 1984 was 30.3 . Although it was intended to work with an unselected sample, it was impossible to obtain an unbiased population, as informed consent was required. The study covered only those children whose parents agreed to their participation in the study. Only $89 \%$ of the families gave their consent to this participation. It is probable that those children who participated and remained in the study for longer periods belonged to families more concerned about their children's health, while those who refused participation included the most vulnerable infants. 
Although health education was provided at the local Health Center in the area, the families were often ill-informed and unable to understand the value of health care research. Some families agreed to participate with the expectation of additional benefits, beyond the health care, and dropped out $(24 \%)$ when they realized that this was not forthcoming. Eighty families left the study because they were in transit, without housing and/ or stable jobs.

Further, although the goal was the evaluation the study population without interfering with their privacy during the course of the study, this proved to be almost impossible. At times it was difficult for the pediatricians to carry out their jobs regardless of the situations encountered among acutely needy people. Because the use of self-administered questionnaires was unrealistic with our target population, home visits were necessary to keep track of the ARI episodes. The cost of this kind of study also limited the sample sizes.

\section{Population Dynamics}

We knew in advance that a high turnover was to be expected when working with a deprived urban population. Therefore replacements were included in the sample design to cover the dropouts, and controls were planned to check on the homogeneity of the study population by comparing representative variables among the newly enrolled infants and those who left the study. The turnover increased the dynamics of the data in such areas as age of the children, changes in nutritional status, duration of ARI and numbers of repeated episodes. This in turn made the analysis complex and laborious.

As is often the case in a developing country, all the children in this study were exposed to many of the same adverse risk factors, and so in studies of incidence vs. risk factors, it was generally difficult to identify clear-cut exposures for the development of ARI.

\section{Data Validation and Observer Effect}

From the logistic point of view the use of pediatricians rather than health workers as reporters was a major advantage. There was no need to send the sick children to the Health Center for verification of their illnesses. This avoided significant data loss due to mother's not seeking care. The physicians could perform as "accurate instruments" when visiting the homes, being able to record clearly a broad range of signs and symptoms. They permitted use of diagnostic criteria when recording ARI and lower respiratory disease, not obtainable when health workers or parents managed a self administered questionnaire. In addition pediatricians could recognize other, nonrespiratory morbidities.

Incidence rates had a tendency to decrease as the study progressed. The lowest figures were recorded at the end of the 32 months of follow-up. The reasons for this change were not obvious, but the phenomenon was observed in all 12 countries?.

Factors such as the season of the year and the age of the children were controlled during data analysis. Other factors such as virulence of the agents, predominance of short ARI episodes not detected during the visits every ten days or changes in the mother's behavior as a result of pediatricians the influence could not be excluded. Epidemiologists are also aware of another factor called "the observer effect" related to a lack of persistent detailed attention among both the respondents and pediatricians after repeated visits at short intervals over time ${ }^{6}$.

\section{Field Aspects}

Occasionally it proved difficult to locate the homes of the children enrolled. Many streets were not named and the houses were not numbered. Although eletricity was available in the study area, many homes had no eletrical supply; others had limited or precarious installation. Thus a mechanical foot operated aspirator pump was required for virus sample collection.

Several additional factors threatened the continuity of the surveillance ${ }^{2}$. Pediatricians could not work during repeated periods of strikes involving transportation and health center personne. Heavy rains made some households unreachable. Moreover, to preserve good relations with the families in the study, plans for taking samples from healthy children or bleeding them for serological studies had to be curtailed.

To get the samples to the laboratory within 2 hours of collection, transport between the field and the laboratory had to be carefully planned.

\section{Laboratory Diagnosis}

In order to obtain results comparable with other those of study centers, all the laboratory methods had to be standardized. Those in use locally were reviewed and modified when required, to ensure 
standardization and accuracy. The introduction of new fastidious cell lines for respiratory viruses required added training in workshops organized for all study virologists. A similar workshop was needed to standardize media and methods for detection of bacterial pathogens. Equipment and human resources were upgraded to enable us to cope with the amount of work planned.

\section{Data Management}

Bulky data management was the biggest challenge for this program. The supervision out of the quality of the collected data and the feeding of them into a computer were time-consuming tasks for the principal investigator.

The precoded forms were reasonably pretested by the trained pediatricians, but the volume of the information that quickly accumulated was far greater than had been foreseen. Too large a data set was collected on each form every ten days and it was realized too late that more restricted information would have fulfilled the study objectives. The clinical information collected was more appropriate for an individual clinical history, than for building up an epidemiological profile of the main characteristics of the ARI episodes. This made computerized data entry, retrieval and analysis more cumbersome than necessary.

\section{Information Dissemination}

When the field work had been completed and the data management problems overcome, publication of results was mandatory. This presented another challenge because of a lack of availability of up-to-date references, guidance was also necessary in the selection of the most appropriate journal for publication of the different types of data obtained, as also regarding for on-site editorial assistance, required for publication in a language foreign to the principal investigator.

\section{Conclusions}

It was known that cohort studies were complex in themselves even in developed countries but the number and range of variables that could impact upon their performance in our environment had been underestimated. These studies required meticulous attention, and dedication as well as a considerable budget. Some of the difficulties could have been prevented had the potential problem been foreseen.
It is hoped that other investigators may benefit from the extensive experience gained during our project in anticipating and planning for difficulties such as those described above. Further, it is hoped that awareness of such problems will assist the readers of studies related to infectious diseases projects in developing countries to recognize the potential bias introduced by often unavoidable problems in population selection, observer monitoring, population dynamics, field site data collection, laboratory development and technology, and data management variables, which are accentuated by the study conditions encountered. It is also important to understand that such factors, when recognized, can be largely controlled in the study design or duly interpreted with the results.

\section{Acknowledgements}

To Drs. P. Charache and B. Selwyn for their comments on the manuscript.

HORTAL, M. \& MENY, M. Dificuldades em estudo de infecções respiratórias em comunidade no Uruguay. Rev. Saúde Pública, 27: 123-6, 1993. Durante estudo sobre infecção respiratória aguda estudada numa coorte de 270 crianças observadas pelos pediatras, cada 10 dias, durante 32 meses, enfrentaram-se problemas metodológicos e logísticos, poucas vezes descritos na literatura. Considerou-se, portanto, importante alertar outros pesquisadores a respeito das dificuldades apresentadas quando se realiza. estudo em nível cumunitário, em um país em desenvolvimento. Apesar do mencionado estudo ter sido planejado com minúcia, enfrentaram-se problemas relativos à população objeto do estudo, à dinâmica populacional, aos aspectos operacionais e ao tratamento da informação. Espera-se que outros pesquisadores possam beneficiar-se da experiência adquirida durante o citado estudo, a fim de evitar ou prever as dificuldades analisadas.

Descritores: Infecções respiratórias, epidemiologia. Estudos de coortes. Fatores epidemiológicos.

\section{Referéncias Bibliográficas}

1. ATENCIÓN primaria de la Salud. UNICEF, 1989. Documento MSP - UNICEF 8/9)

2.BERMAN, S. \& Mc INTOSH, K. Selective primary health care: strategies for control of disease in the developing world. XXI Acute respiratory infections. Rev. Infect. Dis., 7: 674-91, 1985.

3. EKANEM, E.E. Field epidemiology: methodological constraints and limitations in the developing world. Public Health, London, 99: 33-6, 1985.

4. HORTAL, M.; BENITEZ, L.; CONTERA, M.; ETORENA, P.; MONTANO, A.; MENY, M. A community-based study of acute respiratory infections in children in Uruguay. Rev. Infect. Dis., 2: S966-S 973, 1990. 
5. KLEIBAUM, D.G.; KUPPER, L.L.; MORGENSTERN, M. Epidemiologic research principles and quantitative methods. Belmont, Lifetime Learning Publications, 1986.

6. KUMAR, V. Epidemiologic methods in acute respiratory infections. Irdian J. Pediat., 54: 205-11, 1987.

7. SELWYN, B.B. The epidemiology of acute respiratory tract infections in young children: comparison of findings from several developing countries. Rev. Infect. Dis., 12 (supp.8): S870-S888, 1990.
8. VICTORA, C.G.; BARROS, F.C. \& VAUGHAN, J.P. Epidemiologia da desigualdade: um estudo longitudinal de 6000 crianças brasileiras. S. Paulo, Editora Hucitec, 1989.

\author{
Recebido para publicaçấ em 8.9.1992 \\ Reapresentado em 11.1.1993 \\ Aprovado para publicaçäo em 11.1.1993
}

